\section{Abd-Elrahman ${ }^{1}$}

\section{THE BALANCED ROCKET MODEL FOR MEASURING AND MANAGING ORGANIZATIONAL PERFORMANCE}

Abstract: Purpose-The purpose of this paper is to develop a new generic holistic performance measurement framework The Balanced Rocket Model - that incorporates the best of the existing performance measurement frameworks and methodologies.

Design/methodology/approach- The paper reviews performance measurement frameworks and methodologies and identify the key characteristics that they exhibit. Building on these, the researcher seeks to develop a new generalizable holistic performance measurement framework that incorporates the best of the existing frameworks and methodologies and builds upon the latest view to strategic management, the intellectual capital based view (ICBV).

Findings - The findings of the study have been weaved together in a proposed holistic framework for measuring organizational performance (internal and external - financial and nonfinancial - determinants and results). It traces the value creation process from IC (human capital, structural capital and relational capital) to service quality (tangible and intangible outputs) to performance consequences (monetary and non-monetary revenues \& internal and external performance consequences).

Practical implications - The generic holistic model developed for measuring performance can be used by enterprises to evaluate their overall organizational performance periodically.

Originality/value - The generic holistic model for balanced performance measurement is novel and seems suitable for adaptation to different types of organizations and can contribute significantly to existing literature on organizational performance measurement and management.

Research limitations/implications - This paper is a theoretical review, a holistic performance measurement framework has been proposed but has not yet been tested empirically.

Keywords: Performance measures, Organizational performance, Rocket model, Performance measurement framework, Business performance

${ }^{1}$ Corresponding author: Abd-Elrahman Email: abdohassanein123@gmail.com 


\section{Introduction}

One of the most essential questions in business has been why some organizations succeeded whereas others failed. Organizational performance has always been the most important subject for every organization be it profit or non-profit one. It has been very essential for managers to know which factors affect an organization's performance to take proper steps to start them. However, conceptualizing, defining and measuring performance have not been an easy job. Researchers have different views and definitions of performance and it remains to be a contentious dispute among them (Barney, 1991). The central topic concerns with the suitability of various approaches to the concept application and measurement of organizational performance (Venkatraman and Ramanuiam, 1986).

The performance measurement revolution started in the late 1970s with the dissatisfaction with the traditional backward looking accounting systems (Nudurupati et al., 2011). Each organization has its own reasons to measure performance. Businesses measure their performance often to determine whether they meet the needs of their clients, to be able to approve the truth of what they know about their activities and to detect what they do not know, to decide if they are successful or not in the general sense, to assure that the decisions are not based on assumptions or emotions but on real data, to reveal the problematic fields or to find out those areas that could promote and develop (Parker, 2000).

Venkatraman and Ramanujam (1986) suggested in order to measure organizational performance such qualitative criteria as product quality, non-financial market share, launching new products into the market, technological activity, marketing activity in addition to such accounting-based financial criteria as profitability and sales increase (sales return, equity return, investment return and earning per share). As for Dess (1987), he measured business performance using both objective and subjective performance criteria. Assets-return and sales increases were used as objective criteria, and assets return, sales increases and general performance, as subjective criteria.

Hence, the field of organizational performance measurement lacks a consistent body of knowledge. Management researchers in diverse areas as marketing, information systems, operations management, strategy management, human resources, management accounting and control and organizational behaviorare contributing to the field of performance measurement (Franco-Santos et al., 2007). While various and multi-disciplinary research is appealing, it can also promote complications. These different performance measurement approaches have resulted in increasing definitions of a performance measurement system, besides there is little consensus concerning its key characteristics and components. The lack of agreement and consensus on a definition causes confusion and obviously limits the potential for generalizability and comparability of research in this field. This point is clearly illustrated by reviewing the literature of performance measurement frameworks.

The aim of this paper is to review performance measurement frameworks and methodologies and identify the key characteristics that they exhibit. Building on these, the researcher seeks to develop a new generic holistic performance measurement framework - the rocket model - that integrates the best of the existing frameworks and methodologies and builds upon the latest view to strategic management, the intellectual capital based view (ICBV). 


\section{Intermational Quality Conference}

\section{Literature review}

\subsection{Intellectual capital}

The main concepts and definitions of intellectual capital (IC) have been broadly studied by researchers and scholars. The first large wave of IC research started in the late 1990s with several authors' contributions. As a result, IC was defined as the set of all the competences and knowledge that can form the sustained competitive advantage of a company (Stewart, 1997). This implies that IC comprises intellectual property, intellectual material, customer relationships, experience, knowledge, information and core techniques that can be used to make a company rich (Stewart, 1997). Similarly, Edvinsson and Malone (1997) assumed that IC consists of the knowledge, professional skills, organizational technology, applied experience, and customer relationships that create the competitive advantage of firm. Accordingly, IC is not just a static intangible asset, but it is a means to an end (Bontis, 1998). Most researchers conceptualized intellectual capital as encompassing: human capital; structural capital; and relational capital.

Human capital is defined as "the intelligence of the organizational member" (Bontis, 1998 , p. 65) or the accumulated value of investments in the employee's training and competence (Edvinsson and Malone, 1997). It covers features such as the employees' education, qualifications, experience, expertise, pure intelligence, creativity, behavior, know-how, learning capacity, capabilities, skills, commitment, loyalty, motivation, resolve, leadership abilities, values, aptitudes, attitudes, interactions, individual relationships, proactivity, flexibility, risk-taking propensity and intellectual agility (e.g. Bontis, 1998; Youndt et al., 2004; Tovstiga and Tulugurova, 2007; Ling, 2013; Vishnu and Gupta, 2014). Accordingly, all of the human capital attributes stem from the skills and knowledge possessed by and available through the organization's employees.

Structural capital is the organizational elements that support and facilitate the performance of the human capital (Bollen et al., 2005). It comprises factors such as intellectual property (such as patents, trademarks and copyrights),technological elements (such as databases and information systems), routines, procedures and processes, employee-supporting mechanisms and structures, corporate culture, business development plans, strategy, organizational know-how, organizational charts, methods, manuals and programs (e.g. Wu et al., 2008; Hsu and Fang, 2009; Kamukama , 2013; Ling, 2013). On a bit different note, some researches expand structural capital to include relationships with the firm's external networks and environment (Tovstiga and Tulugurova, 2007).

Relational capital is the knowledge that stem from the firm's external relations (Wu et al., 2008). It covers the relations with customers, agents, suppliers, clients, shareholders, partners, competitors, members of the community, informal networks, government, society, the state and industry associations (e.g. Huang and $\mathrm{Wu}, 2010$; Sharabati et al., 2010; Ling, 2013; Marzo and Scarpino, 2016). Accordingly, relational capital may exist at both individual and institutional levels.

Nowadays, the value creation of an organization is extensively the result of its intangible resources and capabilities, i.e. intellectual capital (IC) (Stewart, 1997). Edvinsson and Malone (1997) assumed that the corporate value generated by intellectual assets obviously outweigh that of the tangibles, and the World Bank (2005) reported that 77 per cent of the total global wealth stem from intangibles. Moreover, the exploitation of knowledge resources is increasingly found out to be the source of a company's sustainable ability to compete and succeed in the modern knowledge economy (Stewart, 1997). On the other hand, 
some researches have assumed that IC has a positive impact on a company's innovation capability (Subramaniam and Youndt, 2005). Actually, the huge conceptual literature has argued that there is a positive relationship between IC and firm performance (e.g. Bollen et al., 2005, Ling, 2013).

Lynch (2009) suggested a general framework of strategy that distinguishes three main fields that every organization has to manage in order to succeed:

1) the firm's internal resources;

2) the external environment within which the firm operates; and

3) the firm's ability to add value to what it does.

IC theory fits well within this general framework of strategy and it is clear that the three strategy management areas are fully covered by the IC key components. Human capital and structural capital represent in practice the firm's internal resources; relational capital represents the environment; and last, but not least, the interactions of human capital, structural capital and relational capital represent the ability to generate an economic value.

\subsection{Service Quality}

In the past few decades, researchers and practitioners directed a lot of attention to service quality due to its strong effect on customer satisfaction, customer loyalty, business performance and profitability. Service quality is usually defined as a measure of how well the delivered services level matches customer's expectations (Santos, 2003). As an example, Gronroos (1984) outlined perceived service quality, as "the outcome of an evaluation process, where the consumer compares his expectations with the service he perceives he has received". Furthermore, Parasuraman et al. (1988) defined service quality as the total evaluation of a specific service firm that comes from comparing the performance of that firm with the customers' general expectations of the firms performance in that industry.

Contrasting goods quality, which can be measured with objectivity, service quality (SQ) is elusive and abstract. The unique features of services such as intangibility, inseparability of production and consumption, perishability and heterogeneity make measurement of quality a very complex matter (Ghobadian et al., 1994). The lack and absence of objective measures enforces firms to rely on consumers' perceptions of service quality to define their strengths and/or weaknesses, and design suitable and accurate strategies. This makes it important and imperative to develop managerially helpful and psychometrically sound tools to measure service quality.

The usage of the SERVQUAL scale, presented by Parasuraman et al. (1988), predominated the conceptualization and measurement of the service quality construct. Their measurement of service quality suggests a gap-based comparison of the performance perceptions and expectations of consumers. This measurement model is similar to the disconfirmation paradigm which is a traditional tool used to assess consumer satisfaction (Cronin and Taylor, 1992). Grönroos (1984) proposed the first service quality model, and later other important researchers presented their own conceptualizations (e.g. Parasuraman et al., 1985, 1988, Cronin and Taylor, 1992; Dabholkar et al., 1996; Brady and Cronin, 2001). All these models share a joint feature: They propose a multidimensional service quality conceptualization that is essentially related to the measurement of consumer quality perceptions. Thus, service quality models introduce a framework for understanding the service quality concept, as well as how to measure service quality in each proposed conceptualization.

Service quality plays a critical role in achieving a firm's competitive advantage (Storbacka et al., 1994; Roberts et al., 2003) 


\section{International Cuality Conference 1 .}

$\mathrm{R} U \mathbf{A} \| \mathbf{I} \boldsymbol{Y}$

and affects significantly relationship quality with the customer and customer loyalty (Abdel-Rahman, 2012) (see figure 1). Zeithaml et al. (1996) suggested that satisfaction with service quality has a positive effect on customer loyalty to the organization, which leads to increased organizational profits. Research also shows that service quality leads to attraction of new customers and customer loyalty, positive word-of-mouth, employee satisfaction and commitment, reduced costs, enhanced corporate image, and increased business performance (Berry et al., 1989). Considerable research has been conducted to understand service quality and such causal relationships across a various service settings. Service quality is measured to assess service performance, manage service delivery, diagnose service problems, and as a basis for employee and corporate rewards (Parasuraman et al., 1988).

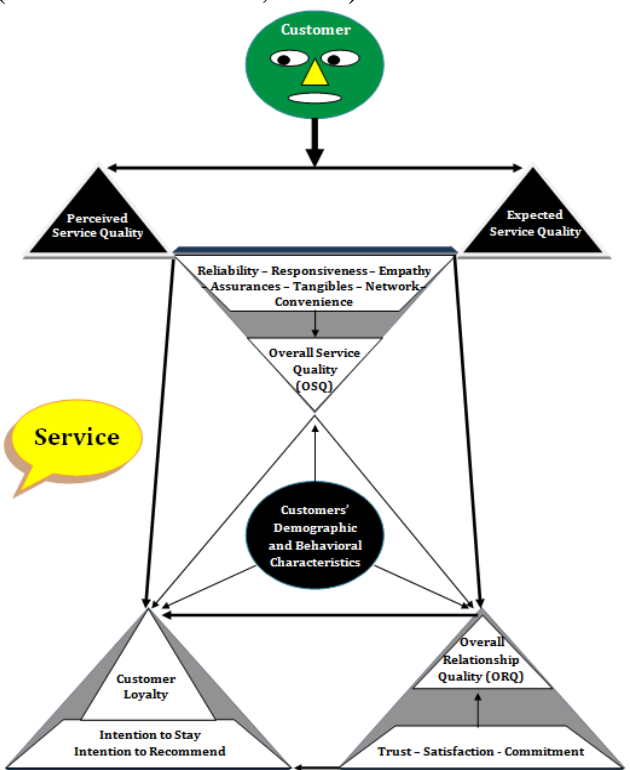

Figure 1. The impact of service quality on relationship quality and customer loyalty (Abd-Elrahman, 2012)

\subsection{Performance measurement definition}

The basic concept of performance is doing today what will lead to an outcome of measured value tomorrow (Neely, 2007). According to Neely et al. (1995, p. 1229), "performance measurement is defined as "The process of quantifying effectiveness and efficiency of actions". Therefore, performance can be defined as the ability of an organization to implement a chosen strategy and performance measurement system is "The set of metrics used to quantify both the efficiency and effectiveness of actions". According to Lebas (1995) Performance measurement is a process of reporting and quantifying the efficiency and effectiveness of the action performed towards achieving organizational objectives. Strategic objectives form the foundations of performance measurement. He describes performance management system as the philosophy supported by performance measurement. It is the organization-wide shared vision, training, incentives, teamwork, etc. that surround the performance measurement activity. It is the application of knowledge and information arising from performance measurement system.

According to Amaratunga and Baldry (2003, p. 174) a PMS is:

"A process of assessing the progress towards realizing pre-determined goals, including information on the efficiency with which resources are transformed into goods and services, the quality of those outputs and outcomes, and the effectiveness of organizational operations in terms of their specific contributions to organizational objectives".

Organizational performance is essential for researchers and managers to evaluate firms and compare them to their competitors. In brief, organizational performance measurement (OPM) is the most significant principle in assessing organizations, their actions, and their environments. It includes 
QUA IIIIY

three types of firm results: (1) financial performance (return on assets, return on investment, profits etc.); (2) shareholder return (economic value added, total shareholder return, etc.); and (3) market performance (market share, sales, etc.) (Neely, 2007).

The performance itself is a firm-specific issue because the performance measures of a certain firm will be determined by its strategic choices. The relationship between measures and performance is affected by the internal measures that the firm uses (e.g., the firm's own key performance indicators (KPIs)) and how these are embedded into control and motivation systems within the firm. In other words, the internal measurement systems used will affect performance at the organizational and individual level. It is essential for the application of performance measurement that a company's tangible and intangible objectives are determined in a way that is more suitable to the requirements and objects of these objectives.

OPM is important for continuing management decision making, strategy planning, and operational effectiveness. An OPM is a systematic process for getting right information about the performance of an organization and the factors that affect performance. It is different from other kinds of evaluations because the primary unit of analysis is the whole organization. Organizations are always seeking to perform, adapt, survive and influence. However, they do not always succeed. Organizations can make organizational assessments to better understand what they can do or should change to promote their ability to perform. This diagnostic method can help organizations get useful data on their performance, determine essential factors that support or prevent their achievement of results and compare themselves to competitors (Neely, 2005).

\subsection{Purpose measurement \\ performance}

To be able to respond to the challenges of a global competitive market, managers need accurate and up-to-date performance information on their business. This performance information have to be accessible, integrated, dynamic and visible to support fast and pro-active decision-making (Nudurupatiet al., 2011). Performance measurement represents the criteria to assess how well people or facilities perform. The outcomes can provide the inspiration to achieve higher levels of effectiveness and competitiveness. So, performance measurement is an important tool for making decisions and judgment. Performance measurement can help managers to answer five strategically important questions: where have we been; where are we now; where do we want to go; how are we going to get there; and how will we know that we got there (Lebas, 1995). Sinclair and Zairi (1995) provided a list of seven topics to indicate the significance and need for performance measurements. Performance measurement:

- enhances improvement;

- makes communication more precise ("say it in numbers");

- can ensure that managers adopt a longterm perspective;

- helps an organization to allocate scarce resources to most attractive improvement activities;

- can influence individuals' motivation by challenging but achievable targets and encourage right organization behavior;

- can support management initiatives, including total quality management and managing change; and

- is central to the operation of an effective and efficient planning, control or evaluation system.

- Parker (2000) mentioned both similar and additional reasons, such as:

- identify success; 


\section{Interinational Cuality Conference 13.}

QUA IIITY

- understand their processes (to confirm what they know or to reveal what they do not know);

- identify whether the organization meets customer requirements;

- identify where problems, bottlenecks and waste exists and where improvements are necessary;

- show if the improvements planned, actually happened; and

- ensure that decisions are based on facts, not emotion, supposition or intuition.

- Bititci, et al. (2002) list the following reasons companies measure business performance:

- To drive improvement

- To maximize the improvement effort effectiveness

- To monitor and control

- To reward and to discipline

- To attain alignment with organizational goals and objectives

Franco-Santos et al. (2007) identified five different categories of business performance measurement system roles. These are:

1) "measure performance" this category covers the role of evaluating performance and monitoring progress;

2) "strategy management" this category covers the roles of planning, strategy formulation, strategy implementation, and focusing attention/providing alignment;

3) "communication" which covers the roles of benchmarking, compliance with regulations and internal and external communication;

4) "influence behavior" this category comprises the roles of managing relationships, rewarding or compensating behavior and control; and

5) "learning and improvement" that comprises the roles of double-loop learning, feedback and performance improvement.

The researcher also concluded that the organizational performance measurement is used for:
1) Planning and decision-making: provide information for planning and decisionmaking and matching plans with goals and objectives;

2) Monitoring: Measuring and recording actual performance;

3) Control: Identifying and attempting to minimize the gap between planned performance and actual performance;

4) Improvement: Identify critical factors and improvement opportunities;

5) Coordination and communication: Groups, teams, internal communication across processes and external communication with stakeholders;

6) Motivation: Align behavior and encourage development, rewards and incentives.

\subsection{Strategic performance measurement systems (SPMSs)}

Contemporary PMSs are multidimensional; use leading and lagging indicators; incorporate financial and non-financial measures; and link performance measures to the strategy of the organization (Lord, 2007). Many contemporary PMSs have a strategic orientation, focusing on providing information which contributes to the identification and accomplishment of strategic objectives. Such PMSs are frequently referred to as SPMSs. SPMSs can be defined as "systems that combine financial, operating, and strategic business measures to gauge how well a company meets its targets" (Gates, 1999, p. 4). Ittner et al. (2003) suggest that SPMS "provides the financial and nonfinancial information that can help in defining the strategies causing the highest potential and impact on achieving the firm's objectives, and aligns management processes, like target setting, decision-making, and performance evaluation, with the achievement of the defined strategic objectives" (p. 715). Ittner et al. (2003) refer to two SPMS approaches the first of which advocates the use of a 
DIFSEAIRCI

various set of financial and non-financial measures, and the second representing a contingency view in which strategic performance measures are aligned with the strategy and/or value drivers. Franco-Santos et al. (2012) clarify the definition of a SPMS system by focusing on its sufficient and necessary conditions. They argue that a SPMS exists when financial and nonfinancial performance measures are utilized to operationalize strategic objectives. This definition is based on a number of suppositions. Firstly, the definition supposes that the role of SPMS is to measure performance for either motivational or informational purposes (irrespective of the organizational level at which performance is evaluated). Secondly, it supposes that SPMS encompass a supporting infrastructure and tools, whether a simple method of data collection and analysis (using, for example, Excel) or a more advanced information system that is supported by organizational resource planning platforms or business intelligence solutions. Finally, it supposes that SPMS comprises definite processes of measure design, information provision and data capture, irrespective of how these processes are fulfilled.

Different SPMS frameworks have some common features and normally include and integrate measures related to: first, customer satisfaction, time, quality, process efficiency, and innovation; second, intangibles and competencies; third, benchmarks and competition; fourth, environmental and social topics; and finally, network and supply chain management. Most also highlight the importance of balancing financial with non-financial indicators; able to enhance organizational learning and strategic alignment; and predict future financial performance (Silvi et al. 2015).

According to literature, SPMS are also characterized by a series of distinctive features. Accordingly Gimbert et al. (2010) define SPMS as those PMS that "provide performance measures in multiple aspects/perspectives, provide a sequence of goals/metrics/ targets/action plans for each perspective, integrate long-term strategic goals and operational goals, display explicit causal relationships between goals and/or between performance measures" (Gimbert et al., 2010, p. 480).

According to Silvi et al. (2015), SPMS models are characterized by: integration of financial and nonfinancial measures, integration of long-term and short-term horizons, inclusion of forward-looking perspectives (e.g. human resource management, innovation), combination of external and internal orientation of the measures including customer, supplier, and competitor perspectives, and identification of causal relationships between the different measures and perspectives. The concept of SPMS model is based on the idea that in practice SPMS may have different levels of sophistication. Many contributions examine the adoption and use of specific SPMS models. In this perspective, the BSC has received the greatest level of attention with numerous studies investigating its characteristics and effectiveness in practice.

\subsection{Trends in performance measurement}

According to the literature, performance measurement has been developed in two phases (Riratanaphong, 2014). In the first phase, which continued until the 1980s, performance measurement primarily focused on financial criteria. The second phase, which began since the late 1980s, revealed that the conventional performance measures had severe limitations because it encouraged short-term thinking, lacked strategic focus and had insufficient local optimization. The development of new performance measures such as internal operations performance, customer satisfaction, shareholder value, economic profit, intellectual capital and intangible assets (Neely and Bourne, 2000) represented a more integrated and holistic method by taking into account the benefits as 


\section{International Cuality Conference 13}

well.

Riratanaphong (2014) found out a similar conclusion that performance measurement has changed from simply focusing on the effectiveness and efficiency of an organization to establish a wider set of criteria including effectiveness, efficiency, productivity, flexibility, creativity and sustainability.

Bititci et al. (2012) reviewed and tackled the evolution and development of the performance measurement field in the context of global and business trends. They concluded that in general the performance measurement field seems to have developed in response to global and business trends. They studied and described issues faced in practice and studied practitioners' responses to these issues leading to better understanding and explanation of the causal relationships. They have also identified some new and rapidly emerging trends that are likely to present practical and theoretical challenges for performance measurement and explored how current knowledge on performance measurement may deal with the emerging context. This results in identification of specific challenges for performance measurement within a holistic systems-based framework.

\subsection{Performance frameworks and criteria}

measurement

The PM frameworks are divided into traditional accounting based, and multicriteria frameworks. The multi-criteria PM frameworks are considered under balanced and multi-criteria, and, cause and effect relationship PM frameworks. The PM frameworks can also be categorized under five types of PM frameworks as shown at Figure 2 (Parida et al. 2015)

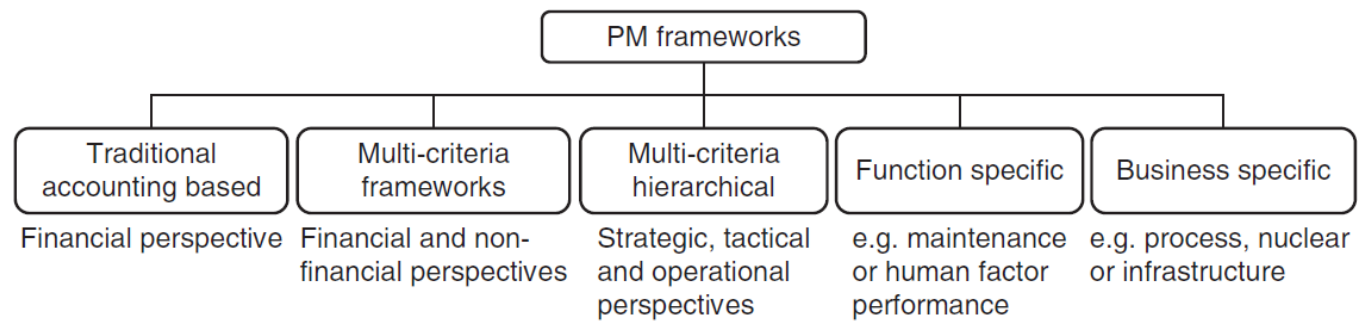

Figure 2. PM frameworks categorization (Parida et al. 2015)

The traditional financial measures are typically criticized for the following (Parida et al. 2015):

- encouraging short termism, like delayed capital investment;

- lack and absence of strategic focus and failure to provide data on quality, responsiveness and flexibility;

- encouraging local optimization, like continuing to manufacture inventory only to keep the people and machines busy;

- encourage managers to work on minimizing variance from standard than to improve continuously; and
- failure to provide information on customer's want and competitors' performance.

Nowadays, there is a great number of measurement systems and conceptual frameworks. (Riratanaphong, 2014), such as the performance measurement matrix of Keegan et al. (1989), the seven performance criteria of Sink and Tuttle (1989), the results-determinants framework of Fitzgerald et al. (1991), the performance pyramid of Lynch and Cross (1991), the balanced scorecard (BSC) developed by Kaplan and Norton (1992), the strategy map developed by the same authors (Kaplan and Norton, 2004), the input-process-output-outcome 
framework of Brown (1996), the performance prism of Neely et al. (2001), the triple-P model developed by Tangen (2005) and the Business Excellence Model developed by the European Foundation for Quality Management. Firms apply these and numerous other PM models to evaluate various sides of organizational success.

According to Sink and Tuttle (1989), organizational performance is a complex interrelationship between different perspectives of performance criteria. They identified seven interrelated performance criteria:

1) Effectiveness: The degree to which the organization achieves what it seeks to achieve, usually expressed as a ratio of actual output to expected output.

2) Efficiency: A ratio of resources expected to be consumed to resources actually consumed.

3) Productivity: Relationships between resources consumed and outputs.

4) Quality: The quality assurance at five checkpoints: upstream systems, inputs, transformation value-adding process, outputs and downstream systems.

5) Quality of work life: Feelings of workforces on key factors, such as compensation, safety, pay.

6) Innovation: A key element in performance sustainability and improvement.

7) Profitability/budgetability: Representing the relationships between cost and revenue.

Another interesting framework that gained reasonably widespread recognition was the performance measurement matrix (PMM) of Keegan et al. (1989). The performance measurement matrix classifies measures as being "cost" or "non-cost", and "internal" or "external". According to Neely et al. (2001) the strengths of this matrix is that it seeks to integrate different categories of business performance and it is a flexible and simple framework that is capable of accommodating any measure of performance.
The SMART (strategic measurement and reporting technique) pyramid developed by Wang Laboratories (Lynch and Cross, 1991) also supports the need to include performance measures that are internally and externally focused. It adds the idea of measures being cascaded down the organization in the way that measures at departmental and work center level reflect the organization vision besides external and internal business unit objectives. The strengths of this framework are such that it clearly links the hierarchical view of business performance measurement to the business process view (Neely and Bourne, 2000).

Following their study of performance measurement in service industries, Fitzgerald et al. (1991) proposed a framework categorizing measures into two basic groups: those that focus on results (financial performance, competitiveness) and those that focus on the determinants of those results (resource utilization, flexibility, quality and innovation). A special strength of the results-determinants framework is that it reflects the notion of causality, confirming that the results obtained today are a function of past business performance in relation to specific determinants. In essence, the results-determinants framework summarizes the theme raised in later debates about designing and deploying performance measurement systems - namely the need to define drivers of performance in order to achieve the desired performance outcomes.

The balanced scorecard (BSC), proposed by Kaplan and Norton (1992), has been the most popular of the performance measurement frameworks. It identifies and incorporates four different and balanced performance perspectives.

1) Financial: Revenue, profitability, sales growth.

2) Customer: Customer satisfaction, customer retention, market research.

3) Internal business processes: Processes to meet or exceed customer expectation. 
4) Learning and growth: How to grow and deal with new challenges.

The authors argue that financial performance, the drivers of it (customer and internal operational performance) and the drivers of constant improvement and future performance should be given equal weighting. The Balanced Scorecard reflects many of the characteristics of other measurement frameworks besides it more explicitly links measurement to the organization's strategy, especially in Kaplan and Norton's more recent writings (see, for example, Kaplan and Norton, 2004).

Despite its widespread use, Neely et al. (2007) stated shortcomings and weaknesses with the balanced scorecard. It does not consider a number of earlier frameworks features. The nonexistence of a competitiveness dimension, as encompassed in Fitzgerald et al.'s (1991) results and determinants framework is also noted. In its traditional form, the question behind the customer perspective is "How do our customers see us?". No mention is made of the organization's performance relative to its competitors, other than implicitly - namely that the view any organization's customers have of it will be influenced by any experiences they might have had with that organization's competitors. Others critics mention that the balanced scorecard neglects perspectives on supplier performance, human resources and employee satisfaction, product/service quality and environmental/community considerations.

Bradley (2002) classified various performance criteria into six perspectives of business performance according to the BSC concept:

1) Stakeholder perception (customer perspective).

2) Financial health (financial perspective).

3) Organizational development (internal business process perspective).

4) Productivity (learning and growth perspective).
5) Environmental responsibility (internal business process perspective).

6) Cost efficiency (financial perspective). The 'strategy map' - a model also created by Kaplan and Norton - is another framework that is employed to visually embody the cause-and-effect logic of an organization's strategy in the four balanced scorecard perspectives: financial, customer, learning and growth and internal processes (Kaplan and Norton, 2004). They use a top down method that starts with defining the organization's strategic goals by the executive team, and then passing and deploying those goals downward, using the balanced scorecard. They claim that success comes from a strategy-focused organization, which in turn, comes from strategy maps and balanced scorecards.

Kaplan and Norton assume that strategy map represents a generalization of their work with numerous companies for whom they have developed specific strategy maps. This generic map displays the four groups of balanced scorecard measures arranged in a hierarchical style, with financial measures at the top, driven and determined by customer measures, which are, in turn, the result of internal (process) measures, and are supported by innovation and learning measures.

Brown (1996) further developed the concept of linking measures through cause and effect relationships. In his macro process model of the organization, he demonstrates clear links and relationships between five stages in a business process and the measures of their performance. These stages are defined as inputs, processing system, outputs, outcomes and goal respectively. Brown's model proposes a linear series of relationships between inputs, processes, outputs, outcomes and goals, with each earlier factor or stage determining the next. While this is, obviously, an oversimplification of reality, the model is a useful method of distinguishing between various groups of measures. The distinction between output 
and outcome measures has proved particularly popular in the public sector.

According to the performance prism of Neely et al. (2001), performance measurement systems should be developed using five distinct but linked performance perspectives:

- Stakeholder satisfaction. Who are the stakeholders and what do they need and want?

- Strategies. What are the strategies we should apply to satisfy our stakeholders' needs and wants?

- Processes. What are the processes we have to use to allow our strategies to be delivered?

- Capabilities. The combination of people, practices, infrastructure and technology that aid the execution of the organization's business processes (now and in the future): what are the capabilities we need to operate our processes?

- Stakeholder contributions. What do we need and want from stakeholders to keep and develop these capabilities?

Although the Business Excellence Model of the European Foundation for Quality Management and its US equivalent, the Malcolm Baldridge National Quality Award were not designed as performance measurement frameworks, they provide a wider view of performance and address many performance aspects not considered or measured by the balanced scorecard. The Business Excellence Model is a broad management model that explicitly highlights the drivers of performance improvement and defines the result aspects that should be measured. However, the groups for measurement are very broad, and it is a selfassessment rather than an objective measurement framework. While the results aspects are readily measurable, some of the drivers are not (Neely et al. 2001).

Tangen (2005), in the triple P model, defines performance as the umbrella term of excellence that includes productivity and profitability in addition to other non-cost factors like speed, delivery, quality and flexibility. Productivity expresses the relation between output quantity (i.e. correctly produced products which fulfill their specifications) and input quantity (i.e. all resources that are consumed in the transformation process) (Tangen, 2005). Profitability is a monetary relationship which influences price-factors (i.e., the difference between revenues and costs). On the other hand, the terms efficiency and effectiveness are considered cross-functional in regard to the other three terms. Efficiency represents how well the resources of the transformation process are utilized. Effectiveness represents the extent of achieving the desired results.

\subsection{Characteristics of performance} measurement frameworks

The performance measurement frameworks discussed in the previous section show a number of key characteristics that help an organization to identify a suitable set of measures to assess its performance (Neely, 2007).

- The system of measures should provide a brief overview of an organization's performance (e.g. the balanced scorecard).

- The measures have to provide a 'balanced' picture of the business (e.g. the balanced scorecard and the performance measurement matrix).

- The performance measures should be multi-dimensional. The EFQM model provides the broadest indication of performance dimensions to be measured.

- The performance measures should be integrated across the organization's functions and through its hierarchy (e.g. the performance pyramid).

- The performance measurement matrix (PMM) provides comprehensive mapping. However, the PMM provides little indication of the different performance dimensions that should be measured. 
- The performance measurement system should be based on the company's existing strategy (e.g. the performance prism and the strategy map).

- The performance measurement system can provide data for monitoring past performance and planning future performance. This implies the measures should measure both results and the drivers of them (e.g. the resultsdeterminants framework, the balanced scorecard and performance pyramid).

- The performance measures should reflect the "non-core elements" of performance measurement systems. This indicates the need for the performance measures implemented to be consistent with management techniques and improvement initiatives that exist within the organization, such as total quality management, benchmarking, activitybased costing management and business process redesign.

Pike and Roos (2004) suggested five conditions derived from measurement theory for a business measurement system able to measure business performance:

(1) Completeness. If the unit of measurement is the whole company then the company attributes which are to be the subject of measurement must fully describe the company. The meanings of the attributes of business performance must be well defined and their sum must reflect all the resources used by the firm and the ways in which they are used.

(2) Distinctness. This simple requirement aims at removing double counting. An attribute is acceptable as an entity to be measured if there is no element of its meaning which is contained within the meaning of any other attribute.

(3) Independence. Independence relates to the relationships between entities subject to measurement. It requires that the normal mathematical conditions of associativity, transitivity, commutativity, monotonicity and the
Archimedian condition are satisfied. This means that aggregation to overarching measures can be done safely.

(4) Commensurability. To make the measurements and following aggregation valid, they must be observed using a ratio scale and be normalized onto a common scale. Failure to do this will make many conclusions drawn from the data meaningless. Where measures are easily observable physical measures, such as temperature, the correct scale is easily chosen and applied. Many business measures are not of this kind and ratio scale techniques must be used in data collection.

(5) Agreeability. This issue concerns the mapping from the empirical to the numerical system. It requires that the meaning of the attribute in the empirical system is fully reflected in the numerical system where the measurement is actually taken.

Bititci et al. (2005) state that any performance measurement system should be:

1. balanced - i.e. the requirements of different stakeholders (employees, customers, shareholders, environment, society) need to be included;

2. integrated - i.e. relationships between various measures need to be understood;

3. inform strategy - i.e. not be driven by strategy but provide an input to strategy;

4. deploy strategy - i.e. transmit and translate strategic objectives throughout the organization to the critical parts of the organization;

5. focus on business processes that deliver value;

6. be specific to business units;

7. include stakeholder contribution - i.e. the role of the stakeholders and their contribution to the success and failure of a business; and 


\section{RIISIFADCD}

8. include competencies - i.e. capabilities and competencies that determine how value is created and sustained.

On the other hand, until now, researchers have not agreed on a universally accepted best practice due to the following requirements on PM (Striteska and Spickova, 2012):

- must reflect relevant non-financial information based on key success factors of each business;

- $\quad$ must be linked to reward systems;

- must be aligned and fit within a strategic system;

- should be implemented as a means of translating strategy and monitoring business results;

- should be grounded on organizational objectives, critical success factors, and customer needs and should monitor both financial and non- financial aspects" and

- must consequently change dynamically with the strategy.

\section{The Proposed Model}

It is clear from the previous discussion that each of the performance measurement frameworks presented in the literature falls short of satisfying the criteria of business performance measurement in a number of areas. In this research, the proposed model attempts to address the shortcomings of the currently available performance measurement frameworks, while satisfying the identified key criteria (figure 3 ). It is based on the newest strategic management theory (the intellectual capital-based view ICBV) that fits well within Lynch (2009) general framework of strategy that distinguishes three main fields that every organization has to manage in order to succeed:

1) The firm's internal resources;

2) The external environment within which the firm operates; and
3) The firm's ability to add value to what it does.

It is obvious that the three strategy management areas are fully covered by the IC key components. Human capital and structural capital represent in practice the firm's internal resources; relational capital represents the environment; and last, but not least, the interactions of human capital, structural capital and relational capital represent the ability to generate an economic value. The strategy of any organization is related to using its resourced and capitals in the most efficient and effective way to achieve its goals. So, simply to identify the degree of achieving its strategic goals and objectives, the organization must measure its performance consequences as well as the changes in its capitals. The proposed model separates and balances the organizational capitals with the performance consequences and uses the best and most holistic measures that can be aligned and fit within a strategic system.

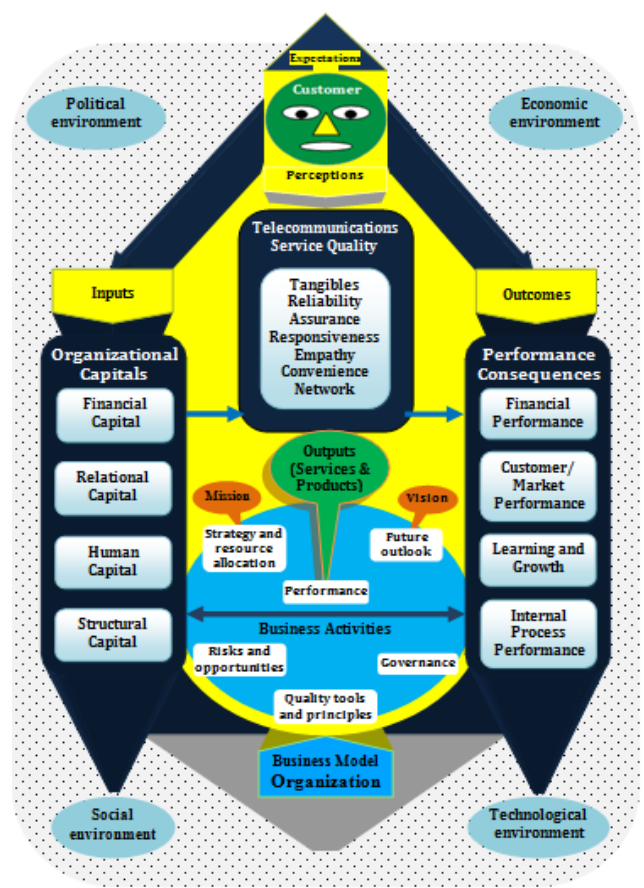

Figure 3. The balanced rocket model for performance measurement 


\section{Intermationall Qualilty Conference}

RUA IITY

The proposed model measures both results and the drivers of them, so it can offer data for monitoring past performance and planning future performance. It offers a brief overview of the organization's performance. It provides a comprehensive presentation of the different performance dimensions that should be measured. It is comprehensive; enabling all measures to be mapped on to it so that gaps in measurement can be identified. The model is considered multidimensional, reflecting all the areas of performance that influence the performance of an organization. This provides a balanced picture of the business, highlighting external (stakeholder) and internal (strategy, process and capability) measures, besides enabling financial and non-financial measures and measures of efficiency and effectiveness throughout the organization. It traces the value creation process from the organization capitals, especially IC (human capital, structural capital and relational capital) to the operational performance of business activities to service quality (tangible and intangible outputs) to performance consequences (monetary and non-monetary revenues \& internal and external performance outcomes). The customer participation forms an important loop of the performance measurement process of any organization through evaluating the quality of its outputs (products and services) from his perspective and against his expectations. This evaluation of outputs quality is preceding to judging the organizational outcomes or performance consequences.

This holistic performance measurement model measures both results and the drivers of them. The performance consequences cover all types of results (financial and nonfinancial \& internal and external) as proposed by Kaplan and Norton (1992) in their balanced scorecard. The performance drivers cover all types of capital or resources (intellectual capital dimensions besides financial and physical capital). The mediating and critical role of outputs quality is not neglected and represents the rocket equilibrium point.

The model measures and monitors both performance determinants and consequences. The determinants must affect and enhance the results and vice versa in a continuous looping provided that the needs and wants of customers and other stakeholders are achieved and satisfied. Also, the measurement model incorporates a mediator variable; namely service quality, because of the organizational complexity and the apparent ambidexterity of the relationship definitely between IC dimensions and firm performance outcomes. Further, firm performance improvements can be perceived to originate from the joint impact of IC and service quality; thus, the whole view of the phenomenon cannot be reached by focusing only on the direct relationships (Kianto et al., 2014).

The most important advantage of this model is its dynamic nature which enables understanding how IC generates value, how it works "in practice" within the organizations and within the capital market. It clearly visualizes and traces the IC dynamics in the value creation process inside and outside the organization and this supports the management and reporting of IC dynamics. This model tries to identify standardized holistic measures for evaluating IC so as to understand its nature and the transformations and interactions among its dimensions and their effects. It traces the value creation process from IC $(\mathrm{HC}, \mathrm{SC}$ and $\mathrm{RC}$ ) and the financial and physical capital to the business activities inside and outside the organization to service quality (tangible and intangible outputs) to organizational performance consequences (monetary and non-monetary revenues \& internal and external consequences). Also, the model can fit all types of organizations. It identifies the broad performance measures and gives any organization the opportunity to identify its specific measures that fit its industry and its internal and external environment. Any 
organization has the opportunity to identify its specific measures for intellectual capital, business activities (operations performance), service quality and performance consequences.

Another advantage of the model comes from its name, the rocket, which implies that there must be a rising motion and there must be a head, a base, sides or wings and a space. The head pulls and direct the rocket motion and the base pushes it upwards. The head is the service quality and customer satisfaction with it that controls the rocket motion speed and direction and the base is the organization that forms the basis for the rocket launch and represents the rocket engine that converts the different capitals into outputs (products \& services). The external environment (political, economic, social and technological) represents the space in which the rocket moves that affects its motion from all sides. The left wing of the rocket is the organizational capitals and resources (financial, human, structural and relational) and the right wing is the organizational performance consequences that result directly from the customer satisfaction with the services quality and indirectly from the use and management of different kinds of organizational capitals. There must be a balance between the two wings and there must be motion compatibility between the head and the base. The rocket movement upwards means enhancing the organizational capitals, the business activities performance and performance consequences.

This model embodies the idea of balance by taking into account the balance inside and between its key measures. With regard to the rocket sides, the performance consequences are measured using the four balanced scorecard dimensions which are compatible and consistent with the four organizational capitals. On the other hand, the rocket head or the service quality perceived by the customer in contrast to his expectations is balanced with the rocket base or the organization and its business model. The equilibrium point of the rocket is the system outputs (products \& services) which is the actual source of value for the customer and subsequently the organization. Customer's expectations about the services or products quality, which the organization seeks to understand and satisfy, is displayed on the rocket top point.

In brief, the purpose of the proposed model is to provide a holistic view of the firm value creation to gain a complete picture of company performance. It explains value creation as an interaction between many elements and identifies value creation as an interaction between the various capital components and the business model. The capital components go beyond the financial and physical capital and include intellectual capital. They are recognized as stores of value and inputs to the business model. The researcher recommends the preparation of an integrated report to explain the capital components that have a material bearing on the organization's ability to create value. The report would need to explain the business model including business activities, initiatives that influence the effectiveness and efficiency of the business activities, and the capacity of the model to adapt to change and to innovate. The report is expected to explain how the capital components are increased, decreased or transformed as a result of the business activities and outputs. Figure (3) provides a complete picture of an organization's value creation process, showing the interaction of the business model and the capital components in the context of the organization's external environment.

\subsection{A systematic view of the value creation process for the customer and organization.}

The best way to depict the value creation process of a certain business is using the notion of a system with inputs, processes, 
outputs and outcomes. As shown in figure (4), the inputs of this system include all types of organizational capitals (financial and physical, human, structural and relational). These four capitals interact with each other producing two dimensions of operational performance (learning and growth and process performance) which in their turn produce one dimension of service quality or outputs quality. Based on the customer satisfaction with the outputs quality, the business achieves its outcomes of customer performance and financial performance. While the financial performance preceded and generated by the customer performance, returns to the organization, the customer performance goes to its customers in the shape of satisfaction, loyalty, market share, etc.

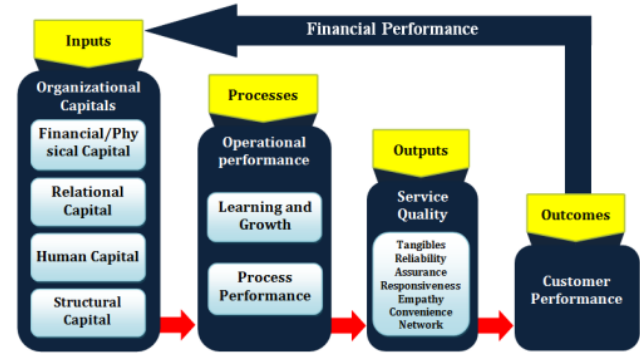

Figure 4. A systematic view of the value creation process for the customer and organization (Source: the researcher)

\subsection{Strategic performance equation of organizations and nations}

It is reasonably acceptable that the strategic performance of an organization is part of the strategic performance of its country or nation and the performance of a nation is the sum of the performance of its organizations. This is not applied on the multi-national companies that work in many countries and their performance becomes part of these countries' performance. In accordance with the four external environment dimensions (economic, political, social and technological) and the four organizational outcomes (financial, customer, learning and growth and process performance), there are four organizational inputs or capitals (financial/physical, relational, human and structural).

Each kind of capital has a source in the external environment and has a conforming outcome. The source of the financial/physical capital is the economic environment that is rooted in the land and the conforming outcome is the financial performance and the source of the relational capital is the political environment that is rooted in the government and the conforming outcome is the customer and market performance. On the other hand, the source of the human capital is the social environment that is rooted in the people and the conforming outcome is the learning and growth performance, while the source of the structural capital is the technological environment that is rooted in the technology and human knowledge and the conforming outcome is the improvement of process performance.

So it can be inferred that the goal of the economic environment is achieving financial profit and the goal of the political environment is enhancing customer satisfaction and loyalty and customer acquisition and retention. Also, the goal of the social environment is achieving learning and growth and the goal of the technological environment is improving process performance.

According to Neely et al. (1995, p. 1229), performance measurement is defined as "The process of quantifying effectiveness and efficiency of actions". As shown in figure (5), the financial performance plus customer performance produce the performance effectiveness and the learning and growth and process performance produce the performance efficiency resulting in the total organizational performance. The organizational outcomes return back to be added to the organizational capitals and external environments and the changes, whether positive or negative, in 
IDIFSIFAIDCI

organizational

capitals and external

organization and nation respectively.

environment express the performance of the

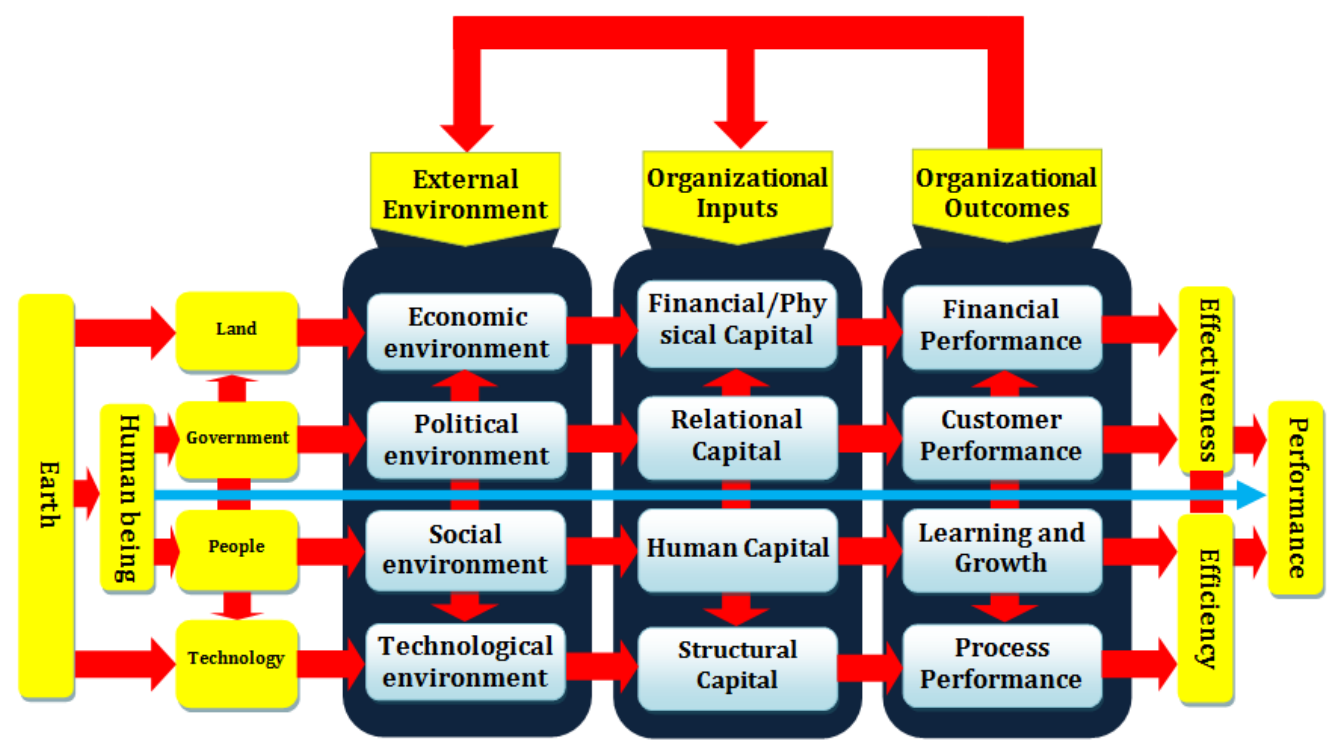

Figure 5. Strategic performance equation of organizations and nations

\section{References:}

Abd-Elrahman, A.H. (2012), "Measuring Service Quality and Its Impact on Relationship Quality with the Customers and Their Loyalty to theOrganization", Master thesis, Productivity and Quality Institute, TheArab Academy for Science \& Technology and Maritime Transport, Cairo, Egypt.

Amaratunga, D. and Baldry, D. (2003), "A conceptual framework to measurefacilities management performance", Property Management, Vol. 21 No.2, pp. 171-189.

Barney, J. (1991), "Firm Resources and Sustained Competitive Advantage",Journal of Management, Vol. 1 No. 17, pp. 99-120.

Berry, L.L., Bennet, D.R., Brown, C.W., (1989), "Service Quality: A ProfitStrategy for Financial Institutions", Dow-Jones-Irwin, Homewood, IL.

Bititci, U., Carrie, A. and Turner, T. (2002), "Integrated performance measurement systems: Structure and dynamics", in Business Performance Measurement: Theory and Practice. Neely, Andrew, editor.Cambridge University Press.

Bititci, U., Garengo, P., Dörfler, V. and Nudurupati, S. (2012), "Performance measurement: challenges for tomorrow", International Journal of Management Reviews, Vol. 14 No. 3, pp. 305-327.

Bititci, U.S., Mendibil, K., Albores, P. and Martinez, M. (2005), "Measuringand managing performance in collaborative enterprises", InternationalJournal of Operations and Production Management, Vol. 25, pp. 333-353.

Bontis, N. (1998), "Intellectual capital: an exploratory study that developsmeasures and models", Management Decision, Vol. 36 No. 2, pp. 63-76.

Bradley, S. (2002), "What's working? Briefing and evaluating workplaceperformance improvement", Journal of Corporate Real Estate, Vol. 4 No.2, pp. 150-159. 


\section{Intermational Qualility Conference 13}

Brady, M.K. and Cronin, J.J. Jr (2001), "Some new thoughts on conceptualizingperceived service quality: a hierarchical approach", Journal ofMarketing, Vol. 65 No. 3, pp. 34-49.

Brown, M.G. (1996), "Keeping Score: Using the Right Metrics to Drive World-Class Performance", New York: Quality Resources.

Cronin, J.J. Jr and Taylor, S.A. (1992), "Measuring service quality: areexamination and extension", Journal of Marketing, Vol. 56 No. 3, pp.55-68.

Dabholkar, P.A., Thorpe, D.I. and Rentz, J.O. (1996), "A measure of servicequality for retailing stores: scale development and validation", Journal ofthe Academy of Marketing Science, Vol. 24 No. 1, pp. 3-16.

Dess,G. (1987), “Concensus on Strategy Formulation and OrganizationalPerformance: Competitors in a Fragmented Industry",StrategicManagement Journal, Vol. 8, pp.259-277.

Edvinsson, L. and Malone, M. (1997), "Intellectual Capital: Realising YourCompany's True Value by Finding Its Hidden Brain power", HarperCollins, New York, NY.

European Foundation for Quality Management, (2003), "EFQM Model forBusiness Excellence", EFQM, Brussels.

Fitzgerald, L., Johnston, R., Brignall, T.J., Silvestro, R., and Voss, C. (1991),"Performance Measurement in Service Businesses", London: CharteredInstitute of Management Accountants.

Franco-Santos, M., Kennerley, M., Micheli, P., Martinez, V., Mason, S., Marr,B., Gray, D. and Neely, A. (2007), "'Towards a definition of a businessperformance measurement system", International Journal of Operations \& Production Management, Vol. 27 No. 8, pp. 784-801.

Franco-Santos, M., Lucianetti, L. and Bourne, M. (2012), "Contemporaryperformance measurement systems: A review of their consequences anda framework for research", Management Accounting Research Vol. 23,pp. 79- 119

Gates, S. (1999), "Aligning Strategic Performance Measures and Results", TheConference Board, New York, NY.

Ghobadian, A., Speller, S. and Jones, M. (1994), "Service Quality Concepts andModels", International Journal of Quality \& Reliability Management, Vol. 11 No. 9, pp. 43-66.

Gimbert, X., Bisbe, J. and Mendoza, X. (2010), "The role of performancemeasurement systems in strategy formulation processes”, Long RangePlanning, Vol. 43 No. 4, pp. 477-497.

Grönroos, C. (1984), “A service quality model and its marketing implications”,European Journal of Marketing, Vol. 18 No. 4, pp. 36-44.

Hsu, Y.H. and Fang, W. (2009), "Intellectual capital and new productdevelopment performance: the mediating role of organizational learningcapability", Technological Forecasting and Social Change, Vol. 76 No.5, pp. 664-677.

Huang, Y.C. and. Wu, Y.C.J. (2010), "Intellectual capital and knowledgeproductivity: the Taiwan biotech industry", Management Decision, Vol.48 No. 4, pp. 580-599.

Ittner, C.D., Larcker, D.F. and Randall, T. (2003), "Performance implications ofstrategic performance measurement in financial services firms",Accounting Organizations and Society, Vol. 28 No. 7, pp. 715-741.

Kamukama, N. (2013), “Intellectual Capital: Firms' Hidden Source of ServiceQuality in the Microfinance Industry in Uganda”, Journal of AfricanBusiness, Vol. 14 No. 3, pp. 150-161.

Kaplan, R.S., and Norton, D.P. (1992), "The balanced scorecard: measures thatdrive performance", Harvard Business Review, Vol. 70 No. 1, pp. 71-9.

Kaplan, R.S., and Norton, D.P. (2004), "Strategy Maps: Converting IntangibleAssets into Tangible Outcomes", Boston: Harvard Business SchoolPress.

Keegan, D. P., Eiler, R. G. \& Jones, C. P. (1989), “Are your performancemeasures obsolete?" Management Accounting, Vol. 70 No. 12, pp.45-50. 


\section{$13^{\text {thin }}$ \\ QUA IIIIY

Lebas, M.J. (1995), "Performance measurement and performancemanagement", International Journal of Production Economics, Vol. 41Nos. 1/2/3, pp. 23-35.

Ling, Y.H. (2013), "The influence of intellectual capital on organizationalperformance knowledge management as moderator", Asia PacificJournal of Management, Vol. 30 No. 3, pp. 937- 964.

Lord, B.R. (2007), "Strategic management accounting", in Hopper, T.,Northcott, D. and Scapens, R. (Eds), Issues in Management Accounting,3rd ed., FT Prentice Hall, Harlow, pp. 135-153.

Lynch, R.L., and Cross, K.F. (1991), "Measure Up: The Essential Guide toMeasuring Business Performance". London: Mandarin.

Marzo, G. and Scarpino, E. (2016),"Exploring intellectual capital managementin SMEs: an in depth Italian case study", Journal of Intellectual Capital,Vol. 17 Iss 1 pp. 27-51.

Neely, A. (2005), "The evolution of performance measurement research:Developments in the last decade and a research agenda for the next",International Journal of Operations \& Production Management, Vol. 25No. 12, pp.1264 - 1277.

Neely, A. and Bourne, M. (2000), "Why measurement initiatives fail",Measuring Business Excellence, Vol. 4, pp. 3-6.

Neely, A., Adams, C. \& Crowe, P. (2001), "The Performance Prism in Practice,Measuring Excellence", The Journal of business performancemanagement, Vol. 5, pp. 6-12.

Neely, A.D., Gregory, M. and Platts, K. (1995), "Performance measurementsystem design - a literature review and research agenda", InternationalJournal of Operations and Production Management, Vol. 15 No. 4, pp.80-116.

Nudurupati, S.S., Bititci, U.S. and Kumar, V. (2011), "State of the art literaturereview on performance measurement", Computers \& IndustrialEngineering, Vol. 60 No. 2, pp. 279-290.

Parasuraman, A., Zeithaml, V.A. and Berry, L.L. (1985), "A conceptual modelof service quality and its implications for future research", Journal of Marketing, Vol. 49 No. 4, pp. 41-50.

Parasuraman, A., Zeithaml, V.A. and Berry, L.L. (1988), "SERVQUAL: amultiple-item scale for measuring consumer perceptions of servicequality", Journal of Retailing, Vol. 64 No. 1, pp. $12-40$.

Parida, A., Kumar, U., Galar, D. and Stenström, C. (2015), "Performancemeasurement and management for maintenance: a literature review",Journal of Quality in Maintenance Engineering, Vol. 21 No. 1, pp. 2-33.

Parker, C. (2000), "Performance measurement", Work Study, Vol. 49 No. 2, pp.63-66.

Pike, S. and Roos, G. (2004), "Mathematics and modern businessmanagement", Journal of Intellectual Capital, Vol. 5 No. 2, pp. 243 - 256.

Riratanaphong, C. (2014), "Performance measurement of workplace change intwo different cultural contexts", Doctoral dissertation, Delft Universityof Technology, Delft.

Roberts, K., Varki, S. and Brodie, R. (2003), "Measuring the quality ofrelationships in consumer services: an empirical study", EuropeanJournal of Marketing, Vol. 37 Nos. 1/2,pp. 169-96.

Santos, J. (2003), "E-service quality: a model of virtual service qualitydimensions", Managing Service Quality, Vol. 13 No. 3, pp. 233-46.

Sharabati, A.A., Jawad, S.N. and Bontis, N. (2010), "Intellectual capital andbusiness performance in the pharmaceutical sector of Jordan",Management Decision, Vol. 48 No. 1, pp. 105-131.

Silvi, R., Bartolini, M., Raffoni, A. and Visani, F. (2015), "The practice ofstrategic performance measurement systems Models, drivers andinformation effectiveness", International Journal of Productivity andPerformance Management, Vol. 64 No. 2, pp. 194 - 227.

Sinclair, D. and Zairi, M. (1995), "Effective process management throughperformance 


\section{Intermational Qualility Conference}

QUA IIIYY

management", Business Process Re-engineering \&Management Journal, Vol. 1 No. 1, pp.7588.

Sink, D. S. and Tuttle, T. C. (1989), "Planning and measurement in yourorganization of the

future", Norcross, USA, Industrial Engineering andManagement Press. Stewart, T. (1997), "Intellectual Capital: The New Wealth of Organizations",Doubleday, New York, NY.

Storbacka, K., Strandvik, T. and Grönroos, C. (1994), "Managing customerrelationships for profit: the dynamics of relationship quality",International Journal of Service Industry Management, Vol. 5 No. 5, pp.21-38.

Striteska, M. and Spickova, M. (2012), "Review and Comparison ofPerformance Measurement Systems", Journal of Organizational Management Studies Vol. (2012), Article ID 114900,13 pages DOI: $10.5171 / 2012.114900$.

Subramaniam, M. and Youndt, M.A. (2005), "The influence of intellectualcapital on the types of innovative capabilities", Academy ofManagement Journal, Vol. 48 No. 3, pp. 450-463.

Tangen, S. (2005), "Demystifying Performance and Productivity", InternationalJournal of Productivity and Performance Management, Vol. 54 No. 1, pp.34-46.

Tovstiga, G. and Tulugurova, E. (2007), "Intellectual capital practices and performance in Russian enterprises", Journal of Intellectual Capital, Vol. 8 No. 4, pp. 695-707.

Venkatraman, N. and Ramanujan, V. (1986), "Measurement of business performance in strategy research: a comparison of approaches", Academy of Management Review, Vol. 11 No. 4, pp. 801-14.

Vishnu, S. and Gupta, V.K. (2014),"Intellectual capital and performance of pharmaceutical firms in India", Journal of Intellectual Capital, Vol. 15 No. 1, pp. 83-99.

Bollen, L., Vergauwen, P. and Schnieders, S. (2005), "Linking intellectual capital and intellectual property to company performance", Management Decision, Vol. 43 No. 9, pp. 1161-1185.

Wu, W.Y., Chang, M.L. and Chen, C.W. (2008), "Promoting innovation through the accumulation of intellectual capital, social capital, and entrepreneurial orientation", $R \& D$ Management, Vol. 38 No. 3, pp. 265-277.

Youndt, M.A., Subramaniam, M. and Snell, S.A. (2004), "Intellectual capital profiles: an examination of investments and returns", Journal of Management Studies, Vol. 41 No. 2, pp. 335-361.

Zeithaml, V. A., Berry, L. L. and Parasuraman, A. (1996), "The behavioral consequences of service quality", Journal of Marketing, Vol. 60, pp. 31-46.

\footnotetext{
Abd-Elrahman

Ain Shams University, Faculty

of Commerce,

Egypt,

abdohassanein123@gmail.com
} 


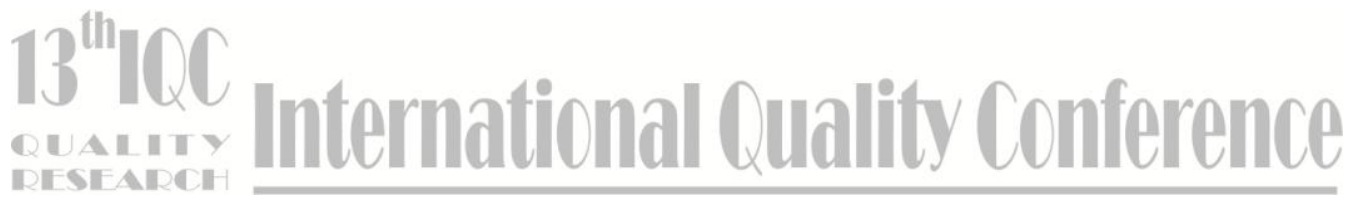

